\title{
Understanding Diversity - Perspectives from University Departments Hosting Large Percentages of International Students
}

\author{
Maureen Snow Andrade \\ Utah Valley University
}

\author{
Norman W. Evans \\ Brigham Young University \\ K. James Hartshorn \\ Brigham Young University \\ Gwyneth Gates \\ Divine Word College
}

The international student enrollment in some university departments has grown to the point that these students are the majority. This study sought to determine the extent to which departments hosting large numbers of international English as a second language (ESL) students demonstrate awareness and planning to address these learners' needs. Analyses were conducted in reference to a framework designed to aid institutions in meeting international ESL students' needs. Findings indicate some awareness of students' needs and related strategies for linguistic and cultural development. They also demonstrate that the proposed framework could foster more intentional strategies to ensure international student success.

Keywords: international students, english language development, cultural adjustment

\section{INTRODUCTION}

The United States attracts over one million international students a year, the largest of any nation (Open Doors, 2016). However, overall percentages of international students in U.S. higher education institutions are much lower than in other English-speaking countries (Open Doors, 2016). In the U.S., international student enrollments comprise $5.2 \%$ of the total enrollment compared to the United Kingdom with $21.1 \%$, Australia at 20.7\%, Canada with 12.9\%, and New Zealand at 12\% (Open Doors, 2016; Project Atlas, 2016).

Percentages of international students vary across institutions as well as programs of study, however. The impact of these students on institutions that host them is potentially greater when they represent a significant percentage of enrollments, and particularly if they speak English as a second language (ESL). Fewer than $5 \%$ of international students from the top 25 sending countries to the United States (representing $80 \%$ of the total) are from English-dominant countries (Institute of International Education, 
2012), indicating that a large majority of international students in U.S. higher education institutions are not native speakers of English.

Previous studies have examined the perspectives of those responsible for admitting and supporting international ESL students (Andrade, Evans, \& Hartshorn, 2014; Ashton-Hay, Wignell, \& Evans, 2015; Spencer-Oatey, Dauber, \& Williams, 2014), and extensive research has been conducted on faculty and student perspectives (Ashton-Hay, Wignell, \& Evans, 2015; Evans \& Andrade, 2015; Evans, Tindale, Cable, \& Hamil Mead, 2009; Frohman, 2012; Ingrams, \& Holzer, 2016; Ritz, 2010; Roy, Lu, \& Loo, 2016; Russell, Rosenthal, \& Thomson, 2009). Research has also identified institutional and national issues (Andrade, Evans, \& Hartshorn, 2016; Bretag, 2007; Benzie, 2010; Haugh, 2016; McGowan, \& Potter, 2008; Sawir, 2011). These studies reflect experiences in the U.S. and in other hosting countries.

An additional need is to understand the perspectives of department heads who have oversight for faculty effectiveness, curriculum, and student success, and particularly in the context of programs with large percentages of international ESL students in the U.S. Such research has not been previously conducted. This is the focus of the current study. Specifically, the research questions are:

To what extent do university department heads in programs with high percentages of international ESL learners demonstrate awareness, vision, and planning focused on developing learners' English language proficiency?

How do university department heads in these programs define and measure students' overall success?

To what extent do current or aspirational strategies and practices in these programs reflect a philosophy of support versus development of learners' English language skills?

\section{LITERATURE REVIEW}

While international ESL students have met admission standards, these students represent a range of proficiency levels and many have need of further language development (Morrison, Merrick, Higgs, \& Le Métais, 2005; Murray, 2010; Trenkic \& Warmington, 2018). Allegations of inequitable admissions practices favoring international students who provide needed tuition dollars, prioritizing profit over student learning, and concerns that international students are graduating without needed English skills are evident (Birrell, Hawthorne, \& Richardson, 2006; Douglas, 2017; Haugh, 2016; Nyland, Forbes-Mewitt, \& Härtel, 2013).

Few U.S. institutions are structured to focus on students' continued English language development after they are admitted (and complete any required ESL work) with the goal of attaining professional level English proficiency, yet this has been a significant issue in Australia where international students stay in the country and work (Birrell et al., 2006; Hancock, Howieson, Kavanagh, Kent, Tempone, \& Segal, 2009a, 2009b; Nyland et al., 2013). As such, curricular innovations aimed at international students' English development after admission and within programs of study are prevalent in that country (Darlington, 2008; Evans et al., 2009; Frohamn, 2012; Ingrams, \& Holzer, 2016; Watty, 2007).

This is an area in which department heads and faculty in the U.S. could take the lead, particularly in programs hosting large percentages of international ESL students, yet as stakeholders these U.S. institutions operate from a philosophy of support (based on beliefs that English language learning is remedial and should occur prior to admission) rather than a developmental perspective (based on language acquisition theory) (Arkoudis \& Starfield, 2007; Arkoudis, Baik, and Richardson; 2012; Chanock, 2007; Haugh, 2014). These beliefs curtail innovative approaches.

\section{Higher Education Practices}

Andrade et al. (2015) describe a "web of disconnects" (p. 24), reflective of U.S. higher education practices. This entails using a single measure to determine proficiency, lack of post-admission testing, limited requirements and provision for continued English language development, and limited tracking of international ESL student success. These issues are the responsibility of a range of stakeholders within a university. Decisions are made about admission standards, generally without interaction with departments or faculty who are best placed to provide feedback regarding the student experience in the classroom. In 
general, institutions are operating on insufficiency of data related to international students (Ingrams \& Holzer, 2016).

Additionally, policy and practice for admitting and supporting international students in the U.S. is not specified by regional or national accrediting bodies, thus consistent standards do not exist. In Australia, where international students comprise a significant percentage of the overall higher education enrollment and may remain in the country to fulfill workforce shortages, national accreditation standards encourage greater awareness "of the role of English language ability in employment outcomes and . . . increased recognition within universities of the fundamental nature of language in learning and academic achievement for all students" (Australian Universities Quality Agency [AUQA], 2009, p. 1).

\section{The Deficit Model}

The lack of attention to English language development in U.S. universities may be partly due to what Arkoudis, Baik, and Richardson (2012) have termed the "deficit model of language learning" (p. 2). This describes the false assumption made by many educators and administrators that if students meet a certain language benchmark (e.g., a TOEFL score of 80), these individuals have the skills required to be successful in their chosen field of study. This assumption is problematic for several reasons.

The deficit model conflicts with major principles of language acquisition theory. Language acquisition is an ongoing process that requires consistent input and development for lasting improvements to occur (Arkoudis et al., 2012). Cummins (2008) adds that while basic interpersonal communication skills take roughly two to three years to develop, the cognitive academic language proficiency needed for university success requires more developmental time - approximately five to seven years. Moreover, certain language skills develop at different rates such as writing, which tends to plateau after first-year English courses (Ferris, 2009; Storch, 2009) rather than improving.

A third and paramount point is that the deficit model fails to consider the cultural and linguistic challenges students face during their time at university (Andrade \& Evans, 2009; Ferris, 2009). Not all language learning experiences are the same. The more different a student's first language is from English, the more challenges that speaker is likely to face during the second language acquisition process (Evans \& Andrade, 2015).

While issues of diversity and equity for English language learners have been heavily researched in K12 (Curtin, 2005; Karanja, 2007; Suarez \& Dominguez, 2015; Myhill, 2004), such research is not as extensive in higher education nor are higher education institutions subject to the same level of state and federal mandates regarding curricular models and accountability measures for ESL students (Wright, 2015). It is generally assumed that once admitted to a higher education institution, domestic and international ESL students have the requisite linguistic skills to succeed and that these skills will improve without intervention (Morrison et al., 2005; Murray, 2010; Trenkic \& Warmington, 2019). This is why the issue of support versus development is critical, and why more information is needed regarding the practices of departments hosting large populations of international ESL students.

Similar to ESL learners in K-12, those in higher education may be marginalized due to their English language skills and cultural differences. These students need culturally and linguistically sensitive pedagogical approaches, accommodative assessment practices, and policies to ensure that faculty and departments are taking full responsibility for enabling them to achieve their educational goals. Instead, some evidence suggests that these students are disadvantaged by assessment methodologies (Smith, 2011) and graduating without the English language skills to get jobs in spite of being advantaged for admission due to their financial contributions (Birrell et al., 2006; Hancock et al., 2009a, 2009b; Nyland et al., 2013).

Educators and administrators have a responsibility to help international ESL students at their institutions succeed. As such, they must develop approaches that respond to the language demands placed on students (Arkoudis et al., 2012). It is imperative that those responsible for the curricula and pedagogies that impact large numbers of ESL students understand that these students are "learning in a language that is not their primary tongue, have specific difficulties compared with native speakers in how they learn, how they think about the content under consideration and how they express themselves" (Smith, 2011, p. 
14). As such, institutions must become more equity minded and analyze gaps in the success of ESL students (Daughtery, 2016), yet most are completely unaware of these gaps (Andrade et al., 2014, 2015, 2016).

\section{METHODS}

Institutions with the highest enrollments of international students in the United States were identified for the study. Disciplinary areas with the most completed degrees from this population and associated departments within these institutions were determined through the Integrated Postsecondary Education Data System (National Center for Education Statistics, 2014) and institutional website searches respectively. Top fields of study for international students in the United States are business and management (20.8\%), engineering (19.2\%), math and computer science $(13.6 \%)$, social sciences $(7.8 \%)$, and physical and life sciences (7.2\%) (Open Doors, 2016). Enrollments in these programs were examined at each high-enrollment institution. Departments were selected on the basis of having a minimum of $15 \%$ of international student completers in a program of study. This cut off was determined based on the assumption that $15 \%$ represented a minimum noticeable presence of international ESL learners in a program (consider that overall percentages of international students in the U.S. average 4-5\% and this includes native English-speakers from countries such as Canada, though about $97.5 \%$ of international students in the United States speak English as a second language (National Student Clearinghouse Research Center [NSC Research Center], 2017).

Of the 4,298 post-secondary, degree-granting institutions operating in the United States in 2017-2018 (National Center for Education Statistics, 2018), 147 (Just over 3\%) were identified for inclusion in this study because of their relatively high numbers of international students. Heads of departments representing the highest concentrations of international students at the institution were contacted and invited to participate a web-based survey designed to elicit information regarding their expectations for global learners, beliefs about their roles in furthering students' English language development, assumptions about language learning and teaching, pedagogical strategies, and assessment methods for determining success. The survey consisted of both Likert-scale-type responses and open-ended questions using the framework as a guide.

Growing out of previous work (Andrade et al., 2014, 2015, 2016), a web-based survey was designed based on the framework depicted in Figure 1. Briefly, views and beliefs refer to assumptions that stakeholders make about language acquisition. These need to be examined as they are the foundation for institutional practices. For example, if the prevailing belief is that international ESL students should possess required English language skills on admission and no further development is needed, opportunities for the latter will be limited and likely in the form of add-on support rather than being integrated into the curriculum.

The assessment component of the framework assists institutions and programs in examining progress at various points in a student's time at the university. This provides stakeholders with needed data upon which to make decisions about programming. Finally, the pedagogy component indicates possible models that could be adopted by institutions. These increase awareness of the advantages of required disciplinebased development that may involve collaboration between language teaching experts and experts from other content areas. However, this component also acknowledges that initiatives must fit within the context or situation of a particular program or institution (e.g., depending on the percentages of international ESL students). 
FIGURE 1

ENGLISH LANGUAGE FRAMEWORK

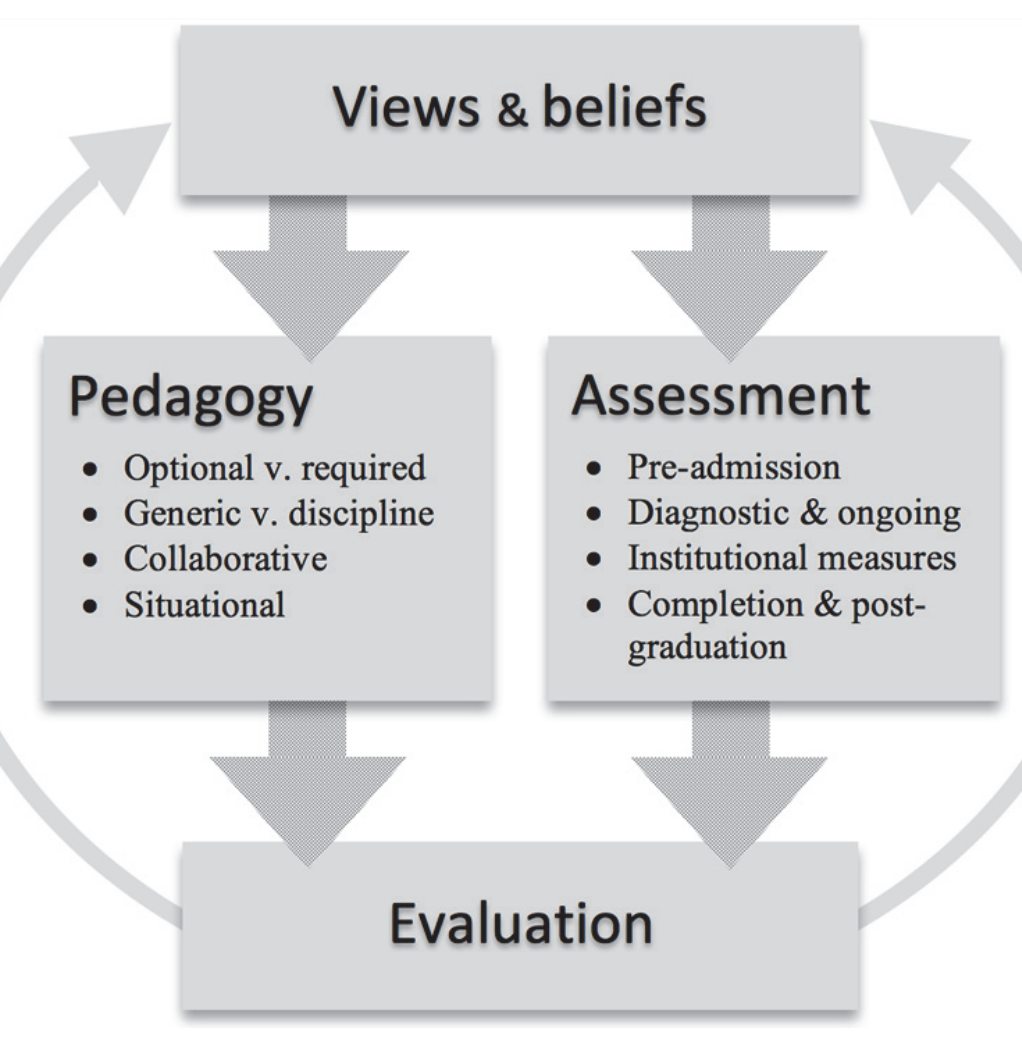

The three key components of the language development framework-views and beliefs, pedagogy, and assessment - are reflected in the research questions as Table 1 indicates.

TABLE 1

FRAMEWORK COMPONENTS AND RESEARCH QUESTIONS

\begin{tabular}{|ll|l|}
\hline Research Question & Framework Element \\
\hline $\begin{array}{l}\text { 1. } \\
\text { To what extent do university department heads in } \\
\text { programs with high percentages of international } \\
\text { ESL learners demonstrate awareness, vision, and } \\
\text { planning focused on developing learners' English } \\
\text { language proficiency? }\end{array}$ & \\
\hline $\begin{array}{l}\text { How do university department heads in these } \\
\text { programs define and measure students' overall } \\
\text { success? }\end{array}$ & Assessment \\
& & Pre-Admission \\
& & Diagnostic \& on-going \\
To what extent do current or aspirational & Success measures \\
strategies and practices in these programs reflect & Completion and post-graduation \\
a philosophy of support versus development of & Optional v. required \\
learners' English language skills? & Generic v. disciplinary \\
& Collaborative \\
\hline
\end{tabular}


The survey was crafted by the researchers over the course of numerous drafts and was designed to target department head expectations for international students, beliefs about their roles in furthering students' English language development, assumptions about language learning and teaching, pedagogical strategies, and assessment methods for determining success. After many internal refinements were made to the instrument, the survey was sent to six individuals within the target pool outside our institutions. They were contacted by phone as asked to pilot the survey to identify additional improvements that could be made. The final version of the survey included both quantitative items and respondent commentary designed to answer the research questions. Many of the quantitative items used a six-point scale (with the following options: strongly disagree $=1$, disagree $=2$, somewhat disagree $=3$, somewhat agree $=4$, agree $=5$, strongly agree $=6$ ) to show the respondent's level of agreement with the various statements (see survey in the Appendix A).

Once the final round of refinements was completed, the survey was sent to 592 email addresses representing department heads of the programs hosting the most international student completers. In addition to the initial invitation, two follow-up invitations were sent over the course of a week and a half. To avoid the risk of aggravating prospective respondents, no further attempts were made to contact department heads beyond this. The delivery software reported that 80 of these surveys were opened. Of the 80 opened surveys, 47 were completed. We cannot confirm how many of the 592 may have received the survey since some email addresses may have been out of date and many institutions have robust email filters that prevent users from receiving certain messages. Nevertheless, we can conclude that the survey was completed by nearly $59 \%$ of those known to have received it and $8 \%$ of those originally targeted.

While 47 department heads completed the survey, responses were limited to 27 different campuses, or 1.74 completed surveys for each campus represented. These campuses included both public and private institutions and were located in both rural and urban settings. They ranged from student enrollments of less than 5000 to more than 30,000 and included bachelor's, master's, and doctorate-granting institutions. Nevertheless, it is important to note that the focus was not on individual campuses themselves but the specific departments with the highest international student enrollments.

Though the response rate was lower than anticipated, we are confident that participating department heads were good representatives of those we targeted. The percentage of international students was as high as $91 \%$ for some programs, with an average being 34\%, nearly eight times the national average. The total number of international students completing the programs represented in the study was 11,495. However, department heads responded to the questions with all international students in their programs in mind (not just those who completed). Thus, this number could be considerably higher given that one-year retention rates are about $61 \%$ for students retained at their current institution and about $73 \%$ for those enrolling elsewhere (NSC Research Center, 2017).

Responses were analyzed in reference to the framework to determine the extent to which departments hosting large numbers of international ESL students had a philosophy of developing students' English language proficiency as opposed to simply meeting short-term needs for academic success. The quantitative data were analyzed for means and standard deviations. Some items were also examined using t-tests or analyses of variance.

The qualitative responses were reviewed and coded based on commonalities across answers to determine patterns (Pell Institute, 2017; Taylor-Powell \& Renner, 2003). The constant comparative method was used to identify initial categories, meanings, and emerging themes. These emerging themes were tested against additional responses and adjusted as needed. The researchers used the framework as a lens to guide the qualitative analysis but not to limit it. The qualitative data provided insights into respondents' perspectives to gain a more complete understanding of awareness, expectations, beliefs, and practices related to students' English language development than could be determined from the quantitative data on its own.

Respondents estimated that, on average, just over $40 \%(S D=18.98)$ of the students enrolled in their department speak English as a second language. In addition, $17 \%$ of the participating institutions were for undergraduate students only, $12 \%$ were exclusively for graduate students, and $71 \%$ served both undergraduate as well as graduate students. 


\section{RESULTS}

The study included both quantitative and qualitative results based on information extracted from the participants' survey responses. The quantitative data will be examined first. Department heads answered several survey items showing their level of agreement with various statements. Mean responses to the first item, ESL students shouldn't need more than minimal support to be academically successful in their program of study, placed department heads between somewhat disagree and somewhat agree $(M=3.61$, $S D=1.29)$. Nevertheless, the range of responses illustrated in Figure 2 suggest some uncertainty on the part of department heads regarding the amount of support that may be needed to ensure the success of their ESL students.

FIGURE 2

ESL STUDENTS SHOULD NOT NEED MORE THAN MINIMAL SUPPORT

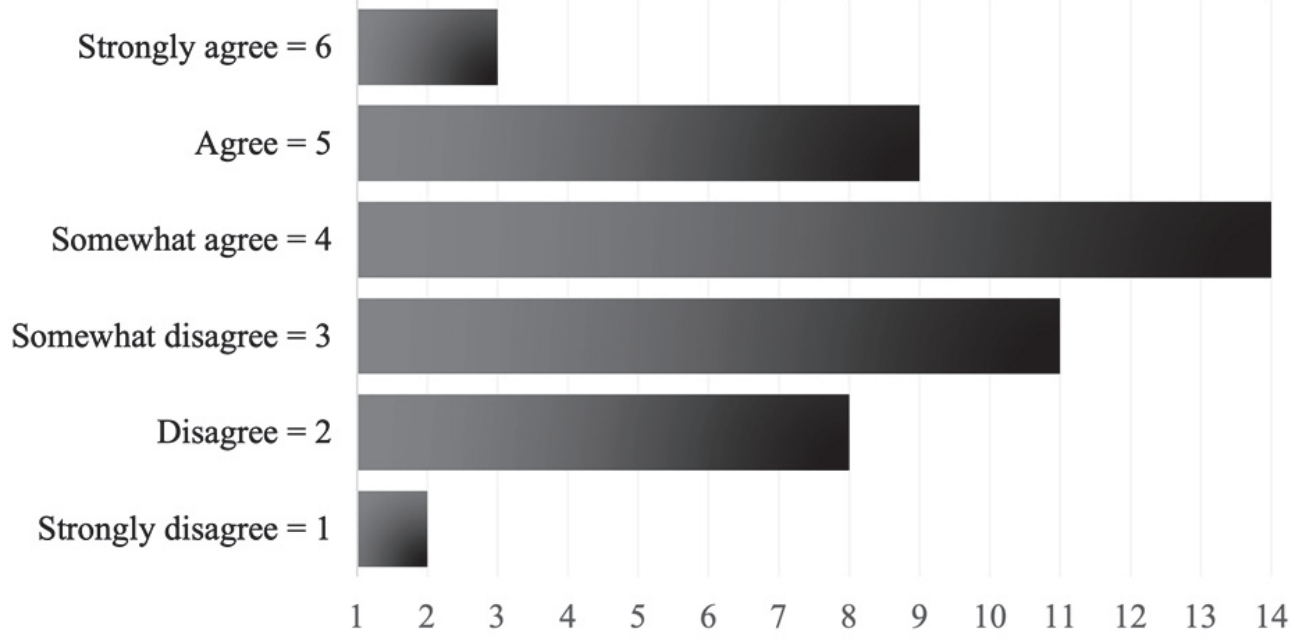

Department heads demonstrated a stronger collective belief in the statement, ESL students naturally improve their English language skills as a result of their studies $(M=4.891, S D=.924)$. Similarly, they also produced a fairly high level of agreement with the statement, ESL students completing programs in my department are expected to have developed the English language skills necessary to be successful in their professions $(M=5.22, S D=.696)$. While this conveys a relatively robust expectation that department heads have about the language development of their students, they seemed less confident regarding the statement, ESL students completing programs in my department demonstrate higher levels of English language proficiency than when they began $(M=4.609, S D=1.022)$. This difference was statistically significant compared to the previous item, based on a paired-sample t-test, $t(45)=3.157 p=.003, d=.70$, and could suggest a discrepancy between expectations and actual observation. This may be true unless department heads feel that students arrive in their departments with the adequate English language skills they need to succeed.

Nevertheless, a related survey question addressed the adequacy of student language skills for academic success upon admission, professional work in the field upon graduation, and ability to go on to graduate study within the field upon graduation. Descriptive statistics are displayed in Table 2. Responses ranged between varying levels of somewhat agree and agree. Differences were not statistically significant across contexts as a group, based on a one-way analysis of variance, $F(2,131)=2.069, p=.130$, suggesting slightly reserved confidence in their students' language ability across these contexts. 
TABLE 2

CONTEXT AND LEVELS OF ADEQUATE ENGLISH SKILL

\begin{tabular}{lll}
\hline Context & $M$ & $S D$ \\
\hline Academic success upon admission & 4.489 & 1.218 \\
Professional work in chosen fields upon graduation & 4.756 & 1.004 \\
Graduate study in chosen fields upon graduation & 4.932 & 0.846 \\
\hline
\end{tabular}

Another survey item addressed responsibility for student language development: If an ESL student's English language skills are inadequate for success in the programs in my department, the responsibility for improved language development belongs to the... Response options included student, faculty, department, and university. Descriptive statistics for levels of agreement on this item are included in Table 3. Statistically significant differences were observed, based on a one-way analysis of variance, $F(3,159)=23.988, p<.001$. The general consensus was that responsibility primarily rests on the student. Post hoc analyses show the expectation for students to be responsible for their own learning differed from each of the other options including the university $(p<.001, d=.927)$, the department $(p<.001, d=1.57)$, and the faculty $(p<.001, d=1.819)$, each of which produced a large effect size. The observation that the university should bear more responsibility than the faculty also was significant with an effect size on the border of medium and large $(p<.001, d=.767)$.

TABLE 3

\section{RESPONSIBILITY FOR ENGLISH LANGUAGE DEVELOPMENT}

\begin{tabular}{lll}
\hline Responsibility & $M$ & $S D$ \\
\hline Student & 5.302 & 0.887 \\
Faculty & 3.350 & 1.231 \\
Department & 3.750 & 1.080 \\
University & 4.300 & 1.244 \\
\hline
\end{tabular}

Respondents also demonstrated slight disagreement with additional statements targeting department efforts to effectively identify and address student needs for further language development. These include the statements, As a department, we have determined an approach for diagnosing ESL students' linguistic needs $(M=2.913, S D=1.244)$, and Faculty across programs in my department have identified effective strategies for helping ESL students develop their English language proficiency $(M=3.370, S D=1.218)$.

The qualitative portions of the survey provided participants with the opportunity to express their views related to expectations for students' English proficiency levels, department and faculty strategies for English language development, methods for assessing proficiency, and perspectives on desirable practices if current limitations were removed. This aspect of the study provided further insights into the levels of agreement expressed relevant to the statements on the quantitative portion of the survey, and in particular, highlighted the lived experiences of the participants in terms of their interactions with international ESL learners and linguistic development.

\section{Expectations}

With regard to expectations upon entry, heads of departments identified specific English language skill sets needed by students. These included the ability to understand course readings, communicate well in writing, comprehend lectures, and interact effectively with others. One respondent indicated, "We should expect them to be sufficiently fluent to understand material discussed in class, capable of completing writing assignments with reasonable grammar and capable of interacting effectively with the instructor when asking and answering questions." Department heads also acknowledged an awareness that English language skills would not be perfect: "Basic English writing skills to write a coherent and 
clear essay that is at least moderately grammatically correct. [Students also need] understandable spoken English." "The student should be able to understand written English and spoken English if enunciated clearly and not too quickly." Related to this, participants expected to modify their pedagogical approaches.

I expect to have to explain things more than once to ESL students. Their writing skills usually lag their ability to understand the material. I require them to write essays and present like all students. . . . I will correct their written English but not take off points.

A minority believed that students should "be proficient enough to be able to handle university level courses like a native speaker." However, such comments did not imply native-speaker-like pronunciation and grammatical accuracy; rather, the ability to perform at a comparable level. Indeed, participants acknowledged that native English speakers had varying levels of English abilities.

At our institution, no international student can serve as a TA [teaching assistant] until they pass two English exams. However, students still complain because of the accents. On that we need to consider accents across the U.S. from Boston to Southern.

Comments such as "the student should be able to understand written and spoken English at least at the level of an average American (which is not a very stringent criterion)," or "you must realize that many native speakers don't have a very good understanding of English either, just pick up a newspaper." These examples illustrate realistic expectations of ESL learners on the part of department heads.

Although a few described their expectations in terms of test scores, most participants indicated that scores needed to be accompanied by evidence of "solid verbal and written communication skills in English." One said: "I wish they were better than they are. The university admits with a TOEFL of 80. I find this too low." Another indicated that students "don't always measure up once they get here." Others were similarly concerned, indicating that students are "not yet fully capable to follow/participate in question and answers," or that they are "not yet able to write excellent English, but [have] sufficient [English] to answer exam questions [and complete] homework." One department head said that it "varies," indicating that students "usually enter with fairly strong fundamental skills, but some challenges with spoken or written fluency." Concerns were also expressed about lack of improvement over the time students were in the program and possible social barriers to skill development:

If they do not have good English skills when they join the program, they can improve, but often don't improve a whole lot. The students often times surround themselves with students who speak their language which hinders them from improving their English to a certain degree.

At the point of graduation, participants not only expected fluency, but growth in proficiency. "They should be fluent. They may make non-native mistakes and speak with an accent, but communication should be straightforward and comfortable." The majority of responses indicated that students should improve their skill sets during their course of study, suggesting a belief in a developmental approach to language learning. "Improved writing ability with fewer grammatical errors, stronger vocabulary, better sentence structures. Improved spoken English and more effective communications," and the ability to use English "with more confidence." Also articulated were expectations related to the discipline and careers, such as the ability to "present and publish in English," "communicate ideas clearly in English with potential students and clients," "compete successfully for employment," and "clearly express sequences of formal reasoning and logical deduction in public speaking and teaching environments." 


\section{Skill Development}

When asked how the department and its faculty assisted international English language learners in furthering their linguistic development to be successful in the major and their future careers, responses ranged from coursework in the discipline, mentoring and pedagogical approaches, and external support. A very few indicated that "not much" was being done in this area. In terms of coursework, the following response is illustrative:

There is a substantial emphasis on communication, both written and oral, across our curriculum. Students work on technical writing skills beginning in the introductory courses, through their capstone, where they write and present a senior thesis. They get a lot of feedback and support.

The latter part of this comment also reflects a primary theme of faculty mentoring and facilitating language development. Approaches for this included "opportunities for [students] to present their work," "Pairing up ESL students with strong classmates, tutors or college resources - allowing multiple drafts on papers," faculty attending "seminars on how to effectively help ESL students in their classes," "structured training and evaluation activities helping students to improve their English skills so that they can communicate efficiently during class and can produce cogent written output reliably," having students " present technical material to a group two to four times/semester," and working with students "on presentation skills." Some responses to this question were fairly detailed.

Explain simple rules on articles to our Asian students (no articles in those languages). Focus on creating outlines, revising those multiple times FIRST until all content is covered, so BEFORE writing any prose (to separate the thought processes of making sure the content is there, and making sure the prose is correct). For presentations: teach them to be clear [and] absolutely minimize text on slides.

Others expressed clear goals for linguistic skill development: "As a multicultural community we expect that students, faculty and staff will communicate in many languages with a goal over time of the individual student being capable of being fully conversant and effective in English."

To a lesser extent, department heads indicated using external support services to help students develop their skills. These included stand-alone English language coursework, writing or ESL centers, tutors or department advisors, and professional writing courses. One respondent suggested providing "ESL classes to international students in their first few semesters as well as communication courses. For certain graduate students entering program we have an intensive English program prior to the start of the semester."

When asked about approaches for helping students develop English proficiency needed for future careers, responses indicated similarities to those previously described with an emphasis on communication skills, presentations and research writing, professional development opportunities, and seminars. "We run teacher training workshops specifically for ESL students to prepare them for instructional or academic careers. We also have writing seminars, lab sessions with presentation coaching, and professional mixers specifically involving the ESL students coming through our track." Respondents also indicated some awareness of variations in English skill abilities depending on career choices. "These graduates can find very good jobs, but if their English isn't really strong, then they would not go into academia. There are many very good jobs for economists that are not academia."

\section{Measures to Assess Progress}

Predominantly, participants reported that measures to assess progress in English rely on course assignments, many of which demonstrate English proficiency simultaneously with content mastery. "We have exams, cases, and presentations that allow students to demonstrate proficiency in the material and in English throughout the program." "Grades are based on written work and class participation; they reflect 
indirectly English language proficiency." "Progress is measured by performance in class. As students progress through the program, interactions rely ever more heavily on the student having sufficient English language proficiency." Others referred specifically to students' performance on outcomes measures. This particular comment focuses on program assessment at the undergraduate level.

We do look at our student's proficiency in communicating because that is one of our department learning outcomes. We continue to assess it using various methods [such as] writing samples, assignments that are part of our business communications course, evaluating presentations, etc. As part of the assessment, we do take a close look at ESL students.

In most cases, departments hosting large numbers of ESL students had specific measures that identified learning outcomes associated with linguistic skill that were applicable to both domestic and ESL students. Programs measured proficiency through English or writing intensive courses, thesis projects, research evaluations, candidacy exams, seminar classes, and advisor interviews. Specific to international students, measures included required ESL courses, standardized testing for international teaching assistants, in-house speaking tests, or other testing. The following proficiency measures reflect practices for international graduate students.

At the end of the first year in the program all ESL students must take and pass two English language tests in order to be allowed to teach our undergraduate students. Some sign up for a summer English course. If the students get good teaching evaluations and present well in seminars, then we can see they do not have issues with ESL.

\section{No Limitations}

If department heads had no limitations for what they would do to support the success of international ESL learners, they would focus on the following: small class sizes, coaching on linguistic skills and professional skills, support for presentations and writing, English preparation within the department, increased time for students who are struggling the most, opportunities to work with and mentor students individually, and "social events to help cultural integration and language improvement."

What REALLY helps is to have a serious conversation with each student individually how important English proficiency is for them, now and in the rest of their life/career. Once that point comes across, the students tend to be more committed to go the extra mile to improve.

Two additional areas emerged related to this question. One was related to external support such as more upper level English courses or required ESL courses for students with low proficiency. Overwhelmingly, department heads advocated for the latter. "If there were no limitations, I'd offer every student the opportunity to complete the remedial ESL coursework before starting their major coursework. Some students start [our program] early due to concerns about time and/or money, but then they seem to struggle more." Additionally, they suggested a need for better preparation and screening. "Have them interview in person to assess language skills better and general interview too." "Be more rigorous in screening for language skills."

\section{DISCUSSION}

The results of this study reveal the degree to which departments have discipline-focused approaches for helping the ESL students they host develop the English language proficiency they need for academic and professional success. Overall, department heads expected students to be proficient at entry, identified 
needed skills for success, acknowledged an awareness of challenges associated with language acquisition, and expected learners' skills to improve.

To provide a sense of the findings collectively, as related to the framework, one of four ratings was assigned to each framework component. A rating of initial indicates that departments are only beginning to consider a particular aspect of pedagogy or assessment; emerging shows that departments have made strides forward related to the practice; developed demonstrates that related practices are fully in place, and highly developed that departments are very sophisticated in their application of the framework component (see Figure 3).

FIGURE 3

ENGLISH LANGUAGE DEVELOPMENT FRAMEWORK WITH RATINGS

\section{Pedagogy}



- Optional v. required

- Generic v. discipline

- Collaborative

- Situational

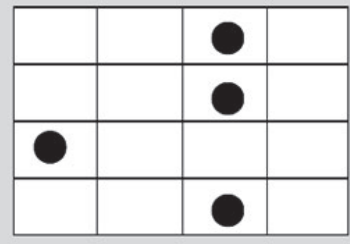

\section{Assessment}

- Pre-admission

- Diagnostic \& ongoing

- Institutional measures

- Completion \& post-graduation
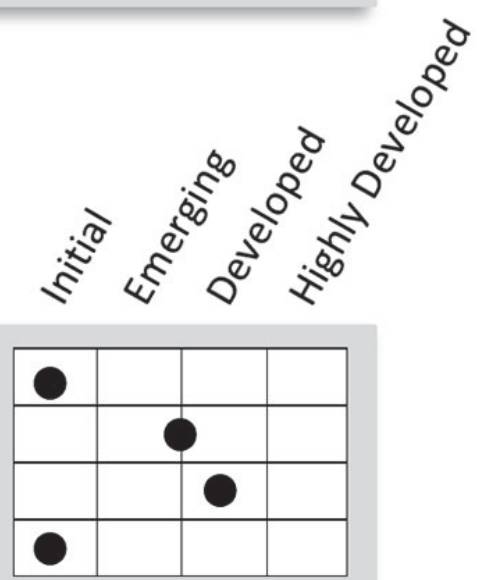

With this rating system in mind, we next turn to the research questions. We include illustrative quotes in this section as evidence for the ratings we assign. Related to the first research question and the views and beliefs aspect of the framework, department heads showed an awareness of language learning and the need for continued language development within the discipline and to prepare for future careers although they may not have organized approaches for structuring this. They had high standards for student performance yet understood that students would make errors. They believed that English language learners should be comprehensible and fluent and be able to compete with native speakers in the classroom and in future careers albeit with imperfect English. They also acknowledged to some degree 
the role of social interaction and cultural understanding. As such, the programs represented by respondents in this study received a rating of developed.

Similarly, participants had a good sense of pedagogical possibilities, another element of the framework, and used a combination of approaches. Some programs required generic writing or ESL courses while others had developed discipline-based or program-specific writing, seminar, or language courses. In most cases, department heads referred to required experiences in the major that, although developed for both domestic and international ESL students, were designed to improve English skills. Program faculty paid particular attention to ESL student performance in these contexts. Desires were expressed to have more required courses or English language development opportunities although practicalities were noted such as resources and credit hour limits. These components of pedagogical practice (optional v. required and generic v. discipline) were considered developed within the programs represented by the department heads in this study.

Few collaborative solutions where ESL professionals might partner with discipline-based professionals were mentioned. This received a rating of initial. Most likely department heads had simply not considered this option. Recommendations for students' English language development were based on situational opportunities and constraints. In particular, department heads identified needs related to discipline-based competencies such as presentations, research and writing, and overall communication skills, and had integrated these into the curriculum. Thus, a rating of developed was assigned.

Related to the second research question about defining and measuring success, reflected in the third component of the framework, as well as the evaluation loop represented in Figure 1, respondents identified some assessment measures focused specifically on ESL students while others on evaluating the skills and progress of all students. Several participants identified the need for better admission screening and higher level entry proficiency. "Before focusing on what to do with students upon their arrival, the university needs to do a better job of screening applicants so that those students admitted arrive with sufficient English language skills to be successful in our programs." As more remains to be done in this area, based on participants' own comments, pre-admission screening was rated as initial.

Participants also mentioned program-specific approaches to initial and on-going English language assessment such as regular interviews with advisors and English screening tests for those teaching undergraduates. Some monitored the progress of students over time. "All our courses from freshmen to senior, require a writing component. We've begun a program of monitoring the progress of a sample of our majors during these years to assess their proficiency." These practices are very positive; however, respondents also somewhat disagreed that their departments had an approach for diagnosing ESL students' linguistic needs. In no cases, did participants indicate using a feedback evaluation loop that would change or inform their views and beliefs or they pedagogical practices. Consequently, this framework component received a rating between emerging and developed. Although departments generally did not use separate assessment measures for international ESL students, the measures they used reflected high expectations for the language skill development of all students.

Participants predominantly focused on success measures that demonstrated students had met expectations for the area of study and for professionals in the field. Accordingly, the element of success measures was rated as developed. Respondents did not indicate they used completion measures such as GPA, retention, or graduation rates as part of their assessment practices. These may not be as meaningful at the faculty-level as classroom- or program-level assessments. Similarly, respondents may not have considered post-graduation measures as a possibility. Therefore, this component of the framework was rated as initial.

Overall, findings indicated clear support for a developmental approach to English language skills rather than a support philosophy, providing insights into the third research question. Participants expected that skills would improve over time although they acknowledged that this did not always happen. "I would love proficiency, but we don't get there. Some are still very poor." Two somewhat opposite comments provide insight into the issue of English language development for international ESL students. 
We know this is generally an issue in the college of engineering to improve ESL language but little campus resources to address it. We find the students do well in technical courses but ones who do not typically have ESL problems. This survey raises questions that, at first glance, seem peripheral to the teaching of physics, in which the main language of interest is mathematics. On reflection, however, I expect to be more attentive to these problems in the future.

This is a very complex topic. Probably 75 to $80 \%$ of our graduate students are ESL students and perhaps $40 \%$ of our undergraduates. The range of language skills is enormous, ranging from students who have the same skills as native English speakers to students who simply cannot function day-to-day in English. As an economics department, we simply do not have the resources to teach English. The university tries to help but I think they are overwhelmed as well.

Both comments indicate the complexities of the issue and the practicalities of time and resources; however, the first participant has reflected on the situation and perhaps formed some ideas for moving forward with new insights, simply as a result of taking the survey. This is the intent of the framework-to provide a structure around which institutions and programs within them can dialogue about international ESL student needs, explore beliefs, and identify opportunities. The specific elements of the framework point to effective practices, but are not intended to be rigid or comprehensive. Approaches to language development must be situational. The findings of this study indicate that a range of possibilities exist and also indicate that other possibilities might yet be considered.

\section{IMPLICATIONS}

The findings provide greater insights into institutional policies and practices for international ESL students in the United States. Previous studies have sought the perspectives of institutional leaders and staff with responsibility for international students (e.g., Andrade et al., 2014, 2015, 2016). While these stakeholders agree that international ESL students are critical to institutional goals, they also recognize that these students would benefit from stronger English language proficiency. In spite of this, most have not considered innovative approaches to English language development (Arkoudis et al., 2012; Harris \& Ashton; 2011). The current study provided a perspective from departments in which faculty have extensive interaction with and responsibility for promoting the academic success of international ESL students.

Institutional discussions across stakeholder groups would be beneficial in determining a common vision for English language development. The English language development framework (Figure 1) can be used to evaluate current paradigms and inform future approaches. Based on the framework, discussions would focus on stakeholders' views and beliefs regarding ESL learners, their levels of preparation, challenges, and ability to be successful. Stakeholders should also consider appropriate pedagogical models as well as situational factors specific to the institution. They need to determine success measures specifically for international ESL students.

Although the framework in this study is illustrated in an English language learning context, it could be applied to any diverse population of learners in higher education who do not fit traditional norms. Do universities and faculty approach these learners from a deficit view (Arkoudis et al., 2012), focusing on what they lack in terms of preparation or cultural norms and expect the learner to adjust (e.g., consider the integration aspect of Tinto's theory of student departure; 1975)? Or, do institutions recognize that learning is developmental and understand institutional and faculty roles in acknowledging and valuing

differences and using pedagogical and evaluation approaches that support learner progress and preparation for future careers? 


\section{CONCLUSION}

The findings of this study indicated some degree of department head awareness and understanding of one population of diverse learners on U.S. higher education campuses-international English language learners - and identified the use of specific strategies to support these students' linguistic and cultural development. It also demonstrated that the proposed framework could further discussions and help structure approaches to more intentional strategies not only for helping international English language learners, but also other diverse learners, attain their academic and professional goals.

Today's global world requires higher education institutions to focus on and take responsibility helping learners develop linguistic and cultural skills along with disciplinary expertise and broader learning outcomes such as critical thinking and communication.

The rapid progress of global higher education is prompting universities in other countries to address the complex issues of learning and teaching in multilingual environments. Given the current prevalence of English in work and professional fields internationally, many universities are seeking better ways for students whose first language is not English to develop their disciplinary English language proficiency through academic studies (AQUA, 2009, p. 1).

The results of this study can assist departments hosting large numbers of international English language learners in determining effective principles, policies, and practices for English language development. The framework presented can also be adapted to create a lens through which to view other populations of learners in higher education settings to ensure their needs and situations are considered from a developmental rather than a deficit perspective.

\section{REFERENCES}

Abendschein, B. F. (2017). A Study of College Professors' Perceptions of International Students in STEM Classrooms at a Technical University. Doctoral dissertation, The University of Memphis.

Andrade, M. S. (2009). The value of a first-year seminar: International students' insights in retrospect. Journal of College Student Retention: Research, Theory, \& Practice, 10(4), 483-506.

Andrade, M. S., Evans, N. W., \& Hartshorn, K. J. (2014). Linguistic support for non-native English speakers: Higher education practices in the United States. Journal of Student Affairs Research and Practice, 51(2), 207-221.

Andrade, M. S., Evans, N. W., \& Hartshorn, J. (2015). Perceptions and realities of ESL students in higher education: An overview of institutional practices. In N. W. Evans, N. J. Anderson, \& W. G Eggington (Eds.), ESL readers and writers in higher education: Understanding challenges, providing support (pp. 18-35). New York: Routledge.

Andrade, M. S., Evans, N. W., \& Hartshorn, J. (2016). Internationalizing higher education: English language policy and practice. In B. Krishna, \& C. Foster (Eds.), Campus support services, programs, and policies for international students. Hershey (pp. 188-208). PA: IGI Global.

Arkoudis, S., \& Starfield, S. (2007). In-course English language development and support. Canberra, Australia: Australian Education International.

Arkoudis, S., Baik, C., \& Richardson, S. (2012). English language standards in higher education: From entry to exit. Camberwell, Australia: Australian Council for Educational Research.

Ashton-Hay, S., Wignell, P., \& Evans, K. (2015). International student transition experience project report. Lismore, Australia: Southern Cross University, Academic Skills, Centre for Teaching and Learning.

Australian Universities Quality Agency. (2009). Good practice principles for English language proficiency for international students in Australian universities. Retrieved from http://www.aall.org.au/sites/default/files/Final_Report-Good_Practice_Principles2009.pdf 
Birrell, B., Hawthorne, L., \& Richardson, S. (2006). Evaluation of the general skilled migration categories. Retrieved from http://www.flinders.edu.au/sabs/nilsfiles/reports/GSM_2006_Full_report.pdf

Bretag, T. (2007). The emperor's new clothes: Yes, there is a link between English language competence and academic standards. People and Place, 15(1), 13-21.

Chanock, K. (2007). What academic language and learning advisers bring to the scholarship of teaching and learning: Problems and possibilities for dialogue with the disciplines. Higher Education Research \& Development, 26(3), 269-280.

Cummins, J. (2008). BICS and CALP: Empirical and theoretical status of the distinction. In B. Street \& N. H. Hornberger (Eds.), Encyclopedia of Language and Education, Volume 2: Literacy (2nd ed., pp. 71-83). New York, NY: Springer-Verlag.

Curtin, E. (2005). Teaching practices for ESL students. Multicultural Education, 12(3), 22-27.

Darlington, M. (2008). Contrasting views: Embedding cultural diversity in the FE Art and Design curriculum. Journal of Further and Higher Education, 32(3), 263-274. Retrieved from $\mathrm{http} / /$ www.tandfonline.com.ezproxy.uvu.edu/doi/full/10.1080/03098770802220447?scroll=top\& needAccess $=$ true

Daughtery, J. L. (2016). California community colleges student equity: ESL and basic skills students. Scholarship and Engagement in Education, 1(1), 1-3.

Douglas, T. (2017, August 17). Douglas Todd: B.C. college faculty feel pressure to 'pass' foreign students. Vancouver Sun. Retrieved from http://vancouversun.com/opinion/columnists/douglastodd-b-c-college-faculty-feel-pressure-to-pass-foreignstudents?utm_source $=$ Academica + Top + Ten\&utm_campaign $=\mathrm{d} 8203049 \mathrm{de}-$ EMAIL_CAMPPAIGN_2017_08_17\&utm_medium=email\&utm_term=0_b4928536cfd8203049de-48927613

Evans, E., Tindale, J., Cable, D., \& Hamil Mead, S. (2009). Collaborative teaching in a linguistically and culturally diverse higher education setting: a case study of a postgraduate accounting program. Higher Education Research and Development, 28(6), 597-613.

Evans, N. W., \& Andrade, M. S. (2015). Understanding challenges, providing support. In N. Evans, N. Anderson, \& W. Eggington (Eds.), ESL readers and writers in higher education (pp. 3-17). New York, NY: Routledge.

Ferris, D. R. (2009). Teaching college writing to diverse student populations. Ann Arbor, MI: University of Michigan Press.

Fiori, L. (2018). Faculty perceptions of the English language skills and knowledge of US academic norms needed by first year international students for accurate assignment completion. Doctoral dissertation, Saint Joseph's University.

Frohman, R. (2012). Collaborative efforts work! Reflections on a two-year relationship between Faculty of Health and International Student Services - Language and Learning Unit. Journal of Academic Language and Learning, 6(3), A47-A58.

Hancock, P., Howieson, B., Kavanagh, M., Kent, J., Tempone, I., \& Segal, N. (2009a). Accounting for the future: More than numbers, Volume 1. Final report Australian Learning and Teaching Council. New South Wales. Retrieved from http://citeseerx.ist.psu.edu/viewdoc/download?doi=10.1.1.169.2764\&rep=rep1\&type=pdf

Hancock, P., Howieson, B., Kavanagh, M., Kent, J., Tempone, I., \& Segal, N. (2009b). Accounting for the future: More than numbers, Volume 2. Strategies for embedding non-technical skills into the accounting curricula., Australian Learning and Teaching Council. New South Wales. Retrieved from https://eprints.usq.edu.au/6333/4/Hancock_Howieson_Kavanagh_etal_v2_2009_PV.pdf

Harris, A., \& Ashton, J. (2011). Embedding and integrating language and academic skills: An innovative approach. Journal of Academic Language \& Learning, 5(2), A73-A87.

Haugh, M. (2014). Complaints and troubles talk about the English language skills of international students in Australian universities. Higher Education Research \& Development, 35(4), 727-740. 
Haugh, M. (2016). Complaints and troubles talk about the English language skills of international students in Australian universities. Higher Education Research \& Development, 35(4), 727-740.

Ingrams, A., \& Holzer, M. (2016). The educational and professional goals of international students in public service degrees. International Journal of Public Administration, 39(14), 1134-1147. Retrieved from https://doi.org/10.1080/01900692.2015.1068328

Institute of International Exchange. (2012). International students: Leading places of origin. Retrieved from http:/www.iie.org/Research-and-Publications/OpenDoors/Data/InternationalStudents/Leading-Places-of-Origin/2010-12

Institute of International Education. (2016). Open doors 2016: Executive summary. Retrieved from http://www.iie.org/en/Who-We-Are/News-and-Events/Press-Center/Press-Releases/2016/201611-14-Open-Doors-Executive-Summary\#.WCz8eXfMz-Y

Karanja, L. (2007). ESL learning experiences of immigrant students in high schools in a small city. TESL Canada Journal, 24(2), 23-41.

Kingston, E., \& Forland, H. (2008). Bridging the gap in expectations between international students and academic staff. Journal of Studies in International Education, 12(2), 204-221.

Maher, M. A., Feldon, D. F., Timmerman, B. E., \& Chao, J. (2014). Faculty perceptions of common challenges encountered by novice doctoral writers. Higher Education Research \& Development, 33(4), 699-711.

McGowan, S., \& Potter, L. (2008). The implications of the Chinese learner for the internationalization of the curriculum: An Australian perspective. Critical Perspectives on Accounting, 19(2), 181-198.

Morrison, J., Merrick, B., Higgs, S., \& Le Métais, J. (2005). Researching the performance of international students in the UK. Studies in Higher Education, 30, 327-337. doi.org/10.1080/03075070500095762

Murray, N. (2010). Considerations in the post-enrolment assessment of English language proficiency: Reflections from an Australian context. Language Assessment Quarterly, 7(4), 343-358.

Myhill, W. N. (2004). The state of public education and the needs of English language learners in the era of 'No Child Left Behind.' Journal of Gender, Race and Justice, 8(2), 393-447.

National Center for Education Statistics. (2014). Completions: Awards/degrees conferred by program (2010 CIP classification), award level, race/ethnicity, and gender. Washington, DC: U.S. Department of Education. Retrieved from https://nces.ed.gov/ipeds/datacenter/InstitutionByName.aspx

National Center for Educational Statistics. (2018). Digest of Education Statistics. US Department of Education, Office of Educational Research and Improvement. Retrieved from https://nces.ed.gov/programs/digest/d18/tables/dt18_317.40.asp

National Student Clearinghouse Research Center. (2017, June 12). Snapshot report: Persistence. Retrieved from https://nscresearchcenter.org/wp-content/uploads/SnapshotReport22PersistenceRetention.pdf

New York University. (2016). NYU at a glance. Retrieved from https://www.nyu.edu/about/newspublications/nyu-at-a-glance.html

Nyland, C., Forbes-Mewitt, H., \& Härtel, C. E. J. (2013). Governing the international student experience: Lessons from the Australian international education model. Academy of Management Learning \& Education, 12(4), 656-673. http://dx.doi.org/10.5465/amle.2012.0088

Open Doors. (2016). Fast facts. Retrieved from http://www.iie.org/Research-and-Publications/OpenDoors/Data/Fast-Facts\#.WC0CEHfMz-Y

Pell Institute for the Study of Opportunity in Higher Education. (2017). Evaluation toolkit. Retrieved from http://toolkit.pellinstitute.org/evaluation-guide/analyze/analyze-qualitative-data/

Project Atlas. (2016). Global mobility trends. Retrieved from https://p.widencdn.net/hjyfpw/ProjectAtlas-2016-Global-Mobility-Trends-Infographics

Ritz, A. A. (2010). International students and transformative learning in a multicultural formal educational context. The Educational Forum, 74(2), 158-166, doi:10.1060/0013172100360S497 
Russell, J., Rosenthal, D., \& Thomson, G. (2009). The international student experience. Higher Education, 60(2), 235-249.

Roy, M., Lu, Z., \& Loo, B. (2016, October). Improving the international student experience: Implications for recruitment and support. New York: World Education Services. Retrieved from http://knowledge.wes.org/WES-Research-Report-Improving-Intl-Student-Experience.html

Sawir, E. (2011). Dealing with diversity in internationalized higher education institutions. Intercultural Education, 22(5), 381-394.

Smith, C. (2011). Examinations and the ESL student-more evidence of particular disadvantages. Assessment \& Evaluation in Higher Education, 36(1), 13-25.

Spencer-Oatey, H., Dauber, D., \& Williams, S. (2014). Promoting integration on campus: Principles, practice and issues for further exploration. UK Council for International Student Affairs. Retrieved from http://www2.warwick.ac.uk/fac/soc/al/research/groups/wacc/activities/publications/

Storch, N. (2009). The impact of studying in a second language (L2) medium university on the development of L2 writing. Journal of Second Language Writing, 18(2), 103-118.

Suarez, M., \& Dominguez, M. (2015). Carrying that weight. ESL teacher negotiations toward advocacy and equity. Radical Pedagogy, 12(2), 46-67.

Taylor-Powell, E., \& Renner, M. (2003). Analyzing qualitative data. University of Wisconsin-Extension, Madison, WI. Retrieved from http://learningstore.uwex.edu/Assets/pdfs/G3658-12.pdf

Tinto, V. (1975). Dropout from higher education: A theoretical synthesis of recent research. Review of Educational Research, 45, 89-125.

Trenkic, D., \& Warmington, M. (2019). Language and literacy skills of home and international university students: How different are they, and does it matter? Bilingualism: Language and Cognition, 22(2), 349-365. https://doi.org/10.1017/S136672891700075X

Watty, K. (2007). Quality in accounting education and low English standards among overseas students: Is there a link? People and Place, 15(1), 22-29.

Wright, W. E. (2015). Foundations for teaching English language learners. Research, theory, policy, and practice, $2^{\text {nd }}$ ed. Philadelphia, PA: Caslon Publishing.

Zhang, Y. L., \& Dinh, T. V. (2017). Advising International Students in Engineering Programs: Academic Advisors' Perceptions of Intercultural Communication Competence. NACADA Journal, 37(2), $33-43$. 


\section{APPENDIX A \\ SURVEY INSTRUMENT}

1. ESL students shouldn't need more than minimal support to be academically successful in their program of study.

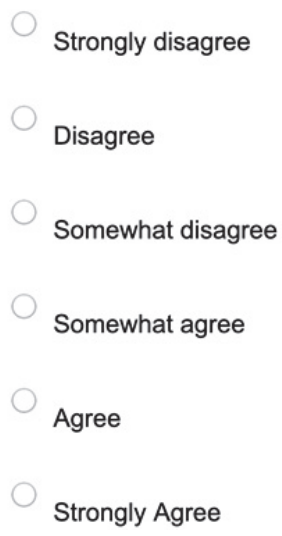

2. ESL students completing programs in my department are expected to have developed the English language skills necessary to be successful in their professions.

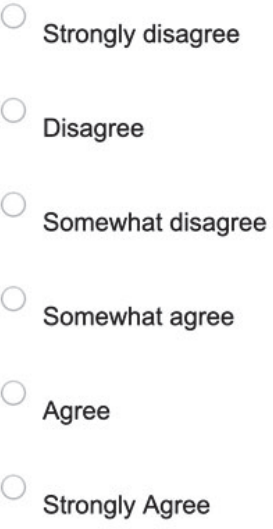

3. ESL students naturally improve their English language skills as a result of their studies.

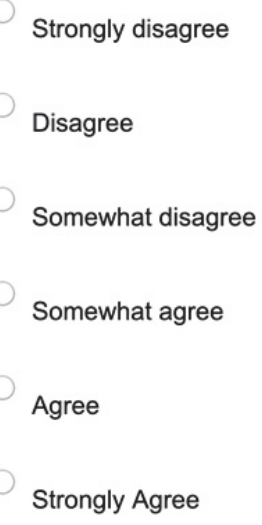


4. Describe your expectations for students' English language proficiency in programs in your department.

Upon entry:

Upon graduation:

5. Faculty across programs in my department have identified effective strategies for helping ESL students develop their English language proficiency.

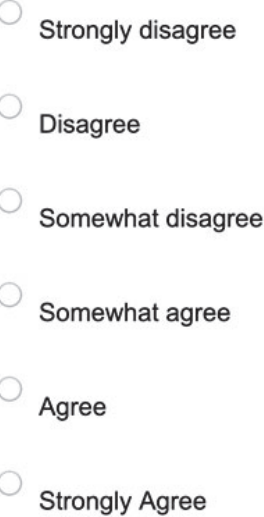

6. Describe the extent to which your department and its faculty assist students in developing their English language skills to be successful in their major study and future careers.

major study:

future careers:

30 Journal of Higher Education Theory and Practice Vol. 20(1) 2020 
7. As a department, we have determined an approach for diagnosing ESL students' linguistic needs.



8. ESL students completing programs in my department demonstrate higher levels of English language proficiency than when they began.

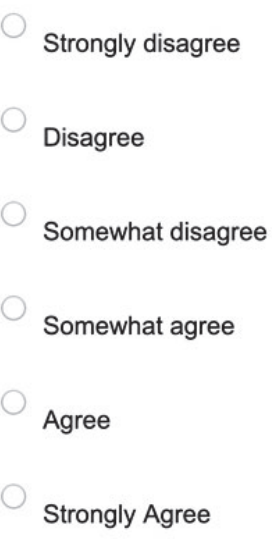

9. Describe the measures you use to assess student progress in programs in your department and the extent to which these measures indicate English language proficiency. 
10. In my opinion, the ESL students in programs in my department have adequate English language skills needed to...

$\begin{array}{lccccc}\text { Strongly } & & \text { Somewhat } & \text { Somewhat } & & \text { Strongly } \\ \text { disagree } & \text { Disagree } & \text { disagree } & \text { agree } & \text { Agree } & \text { agree }\end{array}$

succeed academically upon

admission.

work professionally in their

chosen fields upon graduation.

go on to graduate study in their

chosen fields upon graduation.

11. If an ESL student's English language skills are inadequate for success in the programs in my department, the responsibility for improved language development belongs to the...

$\begin{array}{lccccc} & \begin{array}{c}\text { Strongly } \\ \text { disagree }\end{array} & \text { Disagree } & \begin{array}{c}\text { Somewhat } \\ \text { disagree }\end{array} & \begin{array}{c}\text { Somewhat } \\ \text { agree }\end{array} & \begin{array}{c}\text { Strongly } \\ \text { agree }\end{array} \\ \text { student. } & 0 & 0 & 0 & 0 & 0 \\ \text { faculty. } & 0 & 0 & 0 & 0 & 0 \\ \text { department. } & 0 & 0 & 0 & 0 & 0 \\ \text { university. } & 0 & 0 & 0 & 0 & 0 \\ \text { other. } & 0 & 0 & 0 & 0 & 0\end{array}$

12. If you and your colleagues had no limitations in terms of ways to ensure the success of international ESL students in programs in your department, what would you do differently, if anything? 